$\begin{array}{ll}\text { Italique } & \text { Italique } \\ \text { Poésie italienne de la Renaissance }\end{array}$

XIV | 2011

Varia

\title{
A Reading of «Quand vous serez bien vielle, au soir à la chandelle» by Pierre de Ronsard
}

William J. Kennedy

\section{OpenEdition}

1 Journals

\section{Electronic version}

URL: http://journals.openedition.org/italique/325

DOI: 10.4000/italique.325

ISSN: 1663-4438

\section{Publisher}

Librairie Droz

\section{Printed version}

Date of publication: 1 January 2011

Number of pages: $57-74$

ISBN: 978-2-600-01536-3

ISSN: 1423-3983

\section{Electronic reference}

William J. Kennedy, «A Reading of «Quand vous serez bien vielle, au soir à la chandelle» by Pierre de Ronsard », Italique [Online], XIV | 2011, Online since 24 June 2014, connection on 19 April 2019. URL http://journals.openedition.org/italique/325 ; DOI : 10.4000/italique.325 


$$
\begin{aligned}
& \text { W I L L I A M J. KENNED Y } \\
& \text { A REA D I G O F } \\
& \text { «QUA N D V OUS SEREZ B I E V I E I L L E, } \\
& \text { A U SOIR À LA CHANDELLE» } \\
& \text { B Y PIERRE D E R O N A R D }
\end{aligned}
$$





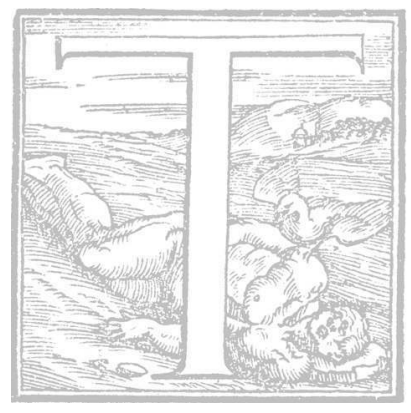

his famous poem made its debut in the fifth edition of Ronsard's Oeuvres complètes (6 February I578) as sonnet 2.24 in the two-part sequence Le premier livre des Sonnets pour Hélène and Le second livre des Sonnets pour Hélène. In the sixth edition of his Oeuvres complètes (4 January I584), the poem is slightly revised and renumbered as sonnet 2.43 in an augmented Sonnets pour Hélène, Livres I et II. The sequence's dramatic action recounts how the aging poet-lover pursues a much younger, unmarried, and intellectually astute woman named Hélène, a member of the queen-mother's courtly retinue. The speaker exudes wit and charm in poems that he lavishes upon her, but she rebuffs him at every turn. For his gifts of poetry, he expects her to thank him with some affective feeling and libidinal gratitude. Instead, she rejects his attentions with no thought about compensating him for them. In this particular sonnet, the speaker fantasizes that after his death Hélène will regret not having rewarded him. The lesson, he concludes, is that we should enjoy our pleasures while they are available to us. Here is the poem: ${ }^{\mathrm{I}}$

Quand vous serez bien vieille, au soir à la chandelle, Assise aupres du feu, devidant et filant, Direz, chantant mes vers, en vous esmerveillant, Ronsard me celebroit du temps que j'estois belle.

Lors vous n'aurez servante oyant telle nouvelle, Desja sous le labeur à demy sommeillant, Qui au bruit de mon nom ne s'aille resveillant, Benissant vostre nom de louange immortelle. Je seray sous la terre et fantôme sans os Par les ombres myrtheux je prendray mon repos:

Vous serez au fouyer une vieille accroupie,

Regrettant mon amour et vostre fier desdain.

Vivez, si m'en croyez, n'attendez à demain:

Cueillez dés aujourd'huy les roses de la vie.

Though the composite sequence of Sonnets pour Hélène I et II portrays a clearly defined action, its development does not dictate a 
bi-partite structure. For example, the beloved does not die as does Petrarch's Laura between the poems in vita di Laura and those in morte di Laura in the Rime sparse, nor does she leave, change her affections or behavior, or break off relations with the poetic speaker as others do in so many Petrarchan sequences. The two-part division seems a nod to the two-part Rime sparse, though without dramatic effect. At the same time, it pursues a revisionary approach to Petrarchan sequences. Its unresolved action tests the speaker's mettle as a lover, casting him at a disadvantage with respect to his age but representing bim as oblivious to the folly of chasing a young woman capable of outwitting him at every turn. The greatest advantage that this speaker possesses is his experience as a writer of earlier poetic sequences in the Petrarchan mode. In Sonnets pour Hélène, Ronsard deploys various Petrarchan styles and archetypes that he had already experimented with witty, allusive, and classicizing on the one hand, along with naïve, affective, and conversational on the other - and he sets them in dialogue with one another. The result affirms a literary competence and poetic know-how that proclaim the author's professionalism at every turn. At this late stage in his career, we find him continuing to write new sonnets. This reading of Quand vous serez bien vieille will consider the poem in its historical context against the evolution of Ronsard's style; in its literary context against a background of sources, models, and analogues; and in an analytic context that examines its rhetorical structure and poetic development.

\section{Historical Context: Ronsard's Stylistic Evolution}

If we can trust a late addition to the third printing (I597) of Claude Binet's Discours de la vie de Pierre de Ronsard (first edition I586, three months after the poet's death), the queen-mother Catherine de' Medici prevailed upon bim to compose a new sonnet sequence for one of her maids of honor, Hélène de Surgères. ${ }^{2}$ We do not know when Ronsard began his poems for Hélène - he likely met her at the Maréschale de Retz's emergent literary salon around I570- but be completed them at his benefice near Croixval in $1576 .{ }^{3}$ Meanwhile, in autumn I572 the poet had found himself adrift on a tide of adverse criticism following the publication of the first four books of his epic Franciade 
(I4 September). In some ways, Ronsard's return to Petrarchan bric suggests that he had faced up to his disappointment with the Franciade and was beginning to move forward. In other ways, it suggests that he still saw bimself a hapless poet enslaved - if not exactly to love, then to the wishes of a royal readership and potential patronage whom none of his serious endeavors had pleased so much as his ephemeral sonnets had done.

Perhaps the major consolation for Ronsard in fashioning Sonnets pour Hélène was that the queen-mother allowed him to use dodecasyllabic verse. Her son, Charles IX, favored the old-fashioned fixedaccent beat of decasyllabic verse and had prevailed upon the poet to use that meter - disasterously, the latter thought - for the Franciade. With Sonnets pour Hélène Ronsard enjoyed freedom to deploy the more flexible alexandrine line that he had earlier experimented with and perfected in various sonnets and in his cosmological and mythological Hymnes. The alexandrine cadences of Quand vous serez bien vieille prove fluid and transformative as they match rhythm to meaning in complex ways. We may represent the chiasmic clustering of syllables in word and phrase groups in the poem's first line as $42 \mid 24$, with its shift in lines 3 and 4 to staccato rbythms of $24 \mid 24$ when Hélène mentions the poet's name and regrets her old age. In lines 7 and 8 a parallel clustering of $33 \mid 33$ accompanies the awakening of Hélène's servants to the sound of Ronsard's name. In the third quatrain the chiasmic clustering of 33142 and 42133 in lines 9 and 10 and the parallel clustering of 33133 in lines II and I2 accentuate the divergent circumstances of Ronsard's death and Hélène's senescence. In the final lines the exhortation to enjoy life shifts to a $24 \mid 33$ cadence that re-integrates the contrasting cadences of earlier lines.

Ronsard's experiments in alexandrine verse were hard won. The poet had published his first major volume of poetry, Les quatre premiers livres des Odes, in January I5so, with an Avis au lecteur in which he derided Petrarchan sonnets as "ce qui n'est rien» 'little puffballs'. Two months later in a separately published Ode de la paix, au Roi, he announced plans to write his epic Franciade. When his odes admittedly, some of them composed with high pretension - met with derision from the doyen of court poets, Mellin de Saint Gelais, and followers of Clément Marot, Ronsard retreated to his ancestral home at Vendôme. Here he addressed yet another ode to the future Chancellor 
of France, Michel de L'Hospital, who had defended his efforts.' In it he articulates a bigh conception of the poet's mestier (etymologically

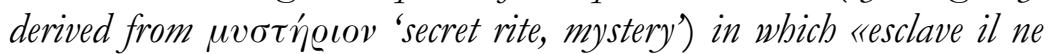
sera / De l'art aux Muses inutile» 'it will not be the slave of any artistry that is of no use to the Muses' (397-98). By l'art, Ronsard means the elementary technical skill of hammering out meter and rbyme. True poetry is the result of divine inspiration, a «sainte fureur» 'sacred fury' that «polira vostre science» 'will burnish your acquired erudition' (407-408). Thanks to this nouminously infused fureur, the poet accomplishes his goals «sans art, sans sueur ne sans paine» 'without any forced technique, without sweat, and without struggle' (454). And yet, as it would turn out in ensuing years, no French poet of his generation would prove more fastidious about polishing his technique, perfecting his skills, and revising his art than Ronsard, and none would expend more sueur and paine than he did to enhance his professional visibility.

In September I5s2 Ronsard published Les Amours, his first sequence of Petrarchan sonnets in decasyllabic meter. Addressed to Cassandre Salviati, it embodied an entrepreneurial effort to attract a wider readership than his odes had earned. Henri II's wife Catherine de' Medici especially enjoyed their Italianate luxuriance, and her tastes prevailed among courtiers for the rest of the Is sos as they encouraged the poet to expand his range of styles and modes in producing yet other variations upon the Petrarchan sonnet form. ${ }^{6}$ What had started out as a bid for recognition became a kind of confinement. A year after the first edition of Les Amours, Ronsard revised its I85 poems and added forty new poems for its second edition; the final redacted sequence for the posthumous seventh edition of his Oeuvres complètes (I587) comprises 222 poems. A persistent theme in this sequence is that the poet's devotion to Cassandre has furnished an impediment to completing his epic Franciade and other exalted poetic projects. ${ }^{7}$ Like the Trojan priestess Cassandra whose name his beloved's name echoes, the poet finds his prophetic vision unheeded, his inspired furor receding into babble, his ambitious designs succumbing to trivialities. Ronsard's foreign models for the early Les Amours had been Petrarch and other illustrious Italian poets such as the chief proponent of Petrarchan style, Pietro Bembo, and the great master of Italian form and carefully-wrought style, Lodovico Ariosto. His domestic models had been French precur- 
sors in the sonnet mode: Clément Marot, who translated a balf-dozen of Petrarch sonnets in I539; Maurice Scève, who published a Petrarchan-like sequence of 449 dizains titled Délie in Is44; Pontus de Tyard who had published his own Petrarchan sequence titled Erreurs amoureuses in November I549; and especially bis close friend Joachim Du Bellay whose manifesto for the future of French letters, Deffence et illustration de la langue française, and its accompanying sonnet sequence Olive (April I549, expanded in October I550) deeply influenced his own efforts. ${ }^{8}$

As Ronsard sought to expand his readership and cultivate his patronage throughout the Is sos, he resorted to many different stylistic forms, some of them drawn from imitations of classical texts esteemed by cognoscenti: the short lyrics of the sixth-century B.C. Greek poet Anacreon and his followers on topics of wine, women and song; the epigrammatic poems collected in the fourth-century B.C. and later Greek anthologies, especially on erotic themes; the pastoral poems of Theocritus; the elegiac poems of Callimachus; and the Neo-Latin poems of fifteenth- and sixteenth century writers such as Michael Marullus, Andrea Navagero, and Johannes Secundus. ${ }^{9}$ In I555 be assembled a volume titled La continuation des Amours with seventy sonnets exemplifying these styles in mostly dodecasyllabic meter, all addressed to Marie de Bourgeuil, his real or imagined beloved from the countryside near Tours. Just as Marie's easy-going disposition contrasts with Cassandre's courtly temper, so the affective and conversational range of these sonnets in alexandrine verse contrasts with the witty and allusive range of Ronsard's earlier sonnets in decasyllabic meter. For the first edition of his collected Oeuvres in I560-conceived as an economic venture to publicize bis work, gain prestige, and attract an affluent patronage - Ronsard brought together some 132 poems initiated under various circumstances during the preceding decade. Associating them with the figure of Marie de Bourgeuil and in Is60 bestowing upon them the title Le second livre des Amours, he created a new Petrarchan sequence that deviates from the previous one for Cassandre Salviati.

As the French civil wars of religion erupted with escalating violence during the early Is6os, the Petrarchan sonnet fell out of vogue in courtly circles and Ronsard turned his attention to his polemical Discours, various elegies and occasional poems, and finally to his epic Franciade. 
The last of these works appeared calamitously in print three weeks after the St. Bartholomew's Day massacre in I572. Not coincidently, a renewed interest in Petrarchism was being cultivated at court as a civilizing antidote to the increased violence of religious conflict and civil war. A young arrival at Charles IX's Académie de poésie et de musique and at the salon of the Comtesse (later Maréschale) de Retz. was Philippe Desportes, son of a wealthy merchant from Chartres, whose chaste-minded sonnets and refined translations from Ariosto's Orlando Furioso exemplified the court's newly mannered sensibility. ${ }^{10}$ In retrospect it seemed almost inevitable that Ronsard would try to rival Desportes, and the queen-mother's wishes provided bim with the vehicle of a sonnet sequence to cheer up her morose and somewhat aloof maid-of-honor.

At this newly self-disciplined court, physical contact between the lover and his beloved would have been in bad taste but Ronsard skirts this issue by playing upon the two parties' differences in age and temperamen. Reference to classical precedent was still in vogue, and Ronsard counted on it by associating his Hélène with the daughter of Leda begotten by Zeus, the wife of King Menelaus of Sparta whose flight with a prince of Troy ignited the Trojan War. A sense of the rancor of the French civil war is not far from the surface of Ronsard's sonnets about his battle of wits with this resistant beloved. Hélène may exemplify - at least in the speaker's imagination - the allure of her classical prototype, but the lover is no shining Paris who couples with her through divine intervention. ${ }^{\text {I }}$ He is instead an old Parisian who half-wearily decides to pursue her despite the mismatch of their characters and years. Members of his youthful brigade - among them, Remy Belleau, JeanAntoine de Baïf, and Joachim Du Bellay - have wrinkled up or passed on, and yet Ronsard wants to pretend that Petrarchism hasn't aged at all. The stage is set for a confrontation of strong-willed personalities that inverts the pathos of Petrarch's Rime sparse. These tensions dominate both Le premier livre des Sonnets pour Hélène and Le second livre des Sonnets pour Hélène.

\section{Literary Context: Sources, Models, and Analogues}

Modern editors point to important classical sources for Quand vous serez bien vieille in Tibullus's elegy I.3, Catullus's carmen 5, and 
Ausonius's idyll I4. ${ }^{\mathrm{I}}$ Tibullus's poem provides the setting for Ronsard's sonnet. Its speaker finds himself gravely wounded in a foreign land and doubts that he shall ever return to his beloved Delia. With heightened self-pity, he imagines that Delia's aged chaperone comforts her: "Haec tibi fabellas referat positaque lucerna / deducat plena stamina longa colu; / at circa gravibus pensis adfixa puella / paulatim somno fessa remittat opus.» 'The old woman shall tell thee stories when the lamp is in its place, as she draws the long yarn from the loaded distaff, while all around the maids bend over the toilsome task till sleep steals upon them and the work drops from the tired hand'. ${ }^{3}$ In this poem, the joke falls upon its speaker who wishfully imagines that upon his own death Delia will devote to him a lifetime of mourning. In reality, as Tibullus gently implies, Delia will likely weep for a while and then gradually forget about her lover as a new one attracts her interest: "Et adsidue proelia miscet amor» 'Love never lets his warfare cease' (64). Ronsard's poem captures a flicker of this irony in the speaker's self-absorption, but its final lines modify this response with their Catullan and Ausonian references. From the first verse of Catullus's poem comes the hortatory Vivamus, mea Lesbia, atque amenus 'Let us live, my Lesbia, and let us love', and from Ausonius's idyll comes the imperative conclusion: "Collige, virgo, rosas dum flos novus et nova pubes / Et memor esto sic properare tuum» 'Gather, maiden, the roses while the flower is young and youth is fresh and so be mindful that whatever is your own will hasten away'. ${ }^{4}$ These classical reminiscences frame Ronsard's poem. At its beginning is the speaker's willful projection of Hélène as an unloved old woman; at its end is the speaker's exhortation to her as a young woman to enjoy now the pleasures of love. No modern commentators have pointed to a dominant source from Petrarch, but several poems in the Rime sparse actively project the speaker's fantasy of the beloved in old age. The first is Petrarch's sonnet I2, «Se la mia vita da l'aspro tormemto / si può tanto schermire» 'If my life can withstand the bitter torment.' ${ }^{\text {is }}$ Here Petrarch's speaker looks abead to an indefinite future when Laura's charms will succumb to old age, "De' be' vostr'occhi il lume spento, / e i cape' d'oro fin farsi d'argento» 'The light of your lovely eyes [will be] dimmed and your hair of fine gold made silver'. In the sestet the speaker expresses his hope that one day he might gather his courage to declare his love («Pur mi darà tanta baldanza Amore»' 'Yet at least Love will give me so much 
boldness') and that she will reward bim with a muted acknowledgment of her affection through «alcun soccorso di tardi sospiri》 'some little help of tardy sighs'. This fantasy of course contravenes the one in Ronsard's poem, whose speaker imagines himself dead before Hélène sings his verse. But it does prepare for an outcome in which the lover prevails over his resistant beloved by provoking her to respond to him. A more forceful result occurs in Petrarch's sonnet 203, with just a whiff of reproach for Laura's intransigence: Lasso, ch' i' ardo et altri non mel crede 'Alas, I burn and I am not believed'. The speaker's evocation of doubting Thomas ("Infinita bellerza et poca fede») 'Infinite beauty and little faith,' cf. Matthew 8.26) spurs his conviction that his poetry might in the future produce an effect upon others: "Quest' arder [...] ne porian infiammar fors' ancor mille»' 'This ardor of mine [...] could perhaps yet inflame thousands'. In Ronsard's sonnet, a similar conviction will link the poem's octave to its sestet. Here the poet's fame will awaken Hélène's servants to praise her for his verses, and she in turn will regret her resistance to him while he was alive.

This tone of regret comes from one of Petrarch's sources, Horace's Asclepiadic Ode 4.IO.6 which slants its irony in a yet different direction. Horace's speaker warns a recalcitrant young man that one day he too will no longer attract suitors, even and especially when he most wants to be requited: "Dices 'beu,' quotiens te speculo videris alterem》 'As often as you gaze in the mirror at your altered features, you shall say: Alas!'. ${ }^{16}$ The twist here is that the Latin poem refers to pederasty. The adolescent boy does not yet have a «faciem hispidam» 'bristly face,' but as the years pass he will grow old and regret his lost opportunity «his animis» 'in a newer frame of mind'. Ronsard likewise suggests that Hélène will pay a stiff penalty for her youthful arrogance. Like Horace's boy, she has been attractive but uninterested and will soon become interested but unattractive. Again like Horace's boy, she remains ungrateful to the lover who has been showering her with gifts of poetry as he expects some sort of requital. In this regard, the Horatian model proves important since its author was the most self-conscious of all Roman poets about tensions between benefaction and gratitude, compensation and autonomy. ${ }^{17}$

This model explicitly influences Pietro Bembo's contrastive reworking of Petrarch's Se la mia vita in his sonnet 87, O superba e crudele, o di bellezza 'O proud, cruel woman, rich in beauty'. ${ }^{8}$ Here 
Bembo's speaker imagines the day when his beloved will experience old age, "quando le chiome d'or caro e lucente, / saranno argento, che si copre e sprezza»' 'when your hair of precious shining gold, which is now covered and tied back, will be silver'. Drawing upon the exclamation of Horace's boy as he looks in the mirror, Bembo sees and hears his ungrateful mistress as she views her transformed features in a cold, uncompromising glass: "E ne lo specchio mirerete un'altra, / direte sospirando: "eh lassa, quale / oggi meco penser?"》 'And you will see yourself as someone different in the mirror, you will say with a sigh: Alas, what memory remains with me today?'. The Horatian touch classicizes Bembo's poem in a self-conscious way that foregrounds the difference between Petrarch and the ancients as well as between Petrarch and the humanist scholars who followed him.

Though there is no evidence that Ronsard read or imitated Bembo's sonnet (it does not appear among the four dozen poems by Bembo in Giolito's I548 anthology of Rime diversi which the French poet drew upon), be would situate himself among humanist scholars who had furthered Petrarch's classical agenda. ${ }^{\text {I9 }}$ In Quand vous serez bien vieille, Ronsard sets Petrarch in dialogue with Horace, but also especially with Tibullus, Catullus, and Ausonius. This dialogue proves revisionary because it recalls a literary history, figured in the topos of an aged beloved reflecting upon her lost beauty. The exchange jostles the antinomies of witty and naïve, allusive and affective, classical and conversational, as they appear in the poet's various models. It also captures and constrains the same antinomies that mark the evolution of Ronsard's style from the witty, allusive, and classicizing sonnets addressed to Cassandre to the naïve, affective, and conversational sonnets addressed to Marie. It points finally to the differences between Ronsard and his chief competitor at the time, Philippe Desportes, whose pallid and often parched Petrarchan sonnets it challenges on the latter's own ground.

\section{Rhetorical Structure and Development}

Quand vous serez bien vieille channels its classical and Petrarchan models into a direct enunciation of the poet's would-be mastery. Projecting Hélène into the future as an elderly woman, the speaker depicts 
her as she sings his verses with a bint of admiration. At the end of the first quatrain, he puts into her reported voice words that she will use to express discomfort at growing old. These same words with their citation of the poet's name will have the potent effect of motivating others to praise Ronsard's evocative skills:

Quand vous serez bien vieille, au soir à la chandelle, Assise aupres du feu, devidant et filant, Direz chantant mes vers, en vous esmerveillant, Ronsard me celebroit du temps que j'estois belle.

'When you will be old indeed, seated at evening by candlelight near the fire, spinning and winding thread, you will say in amazement while singing my verses: Ronsard used to celebrate me when I was young'.

Ronsard's version of this trope, derived from Tibullus's elegy I.3, expresses a sophisticated negotiation of its dramatic possibilities, as Ronsard's now aging speaker imagines a then-to-be very aged Hélène bereft of his living company. This transposition of her role projects a whiff of resistance to fashionable dictates of court poetry and their requirement that the speaker display his poetic talents to an indifferent mistress and an often indifferent readership.

As Hélène's words ventriloquize the speaker's song, they spark in her servants at the end of the octave an admiration not of what she will have become in old age but of what the poet has already conferred upon her in her youth, a gift «de louange immortelle».

Lors vous n'aurez servante oyant telle nouvelle, Desja sous le labeur à demy sommeillant, Qui au bruit de mon nom ne s'aille resveillant, Benissant vostre nom de louange immortelle.

'Then you will have no servant upon hearing such news, already half asleep after her work, who at the sound of my name will not wake up, blessing your name with immortal praise'.

Here the speaker usurps Hélène's words, repeating his own name Ronsard in the poem's original version ("Qui au bruit de Ronsard ne s'aille resveillant») when he fantasizes about his fame. A revision in 
I) 84 wittily replaces the proper noun with «mon nom» where the consonantal repetitions of nasal $\mathrm{m}$ and $\mathrm{n}$ sounds accentuate the contrast of «vostre nom» in the following line. This promotion of Ronsard's name over hers generates - again at Hélène's expense - a withering contrast between him, the object of recognition and admiration, and her, a replacement for Tibullus's "pensis adfixa puella» 'maid bent over her measures of wool. He substitutes his name for hers and then diverts her attention by proclaiming that she will be honored.

In the poem's sestet, the speaker proceeds to elaborate upon the implied contrast between the now-living and then-dead poet on the one hand and the now-disdainful and then-regretful beloved on the other:

Je seray sous la terre, \& fantôme sans os

Par les ombres myrtheux je prendray mon repos:

Vous serez au fouyer une vieille accroupie,

Regrettant mon amour et vostre fier desdain.

'I will be beneath the earth, a phantom without bones: I will take my rest among the shadowy myrtles. You will be an old woman hunched at the fireplace, feeling regret about my love and your proud disdain'.

The phonic shift from the rounded vowels of os and repos to the closed vowels of accroupie (and to the rhyming vie in the final line) allows us to hear in the first instance the trailing «ob» of her regret and in the second the whining «ayy» of her self-reproach. In the poem's conclusion, the speaker formulates his advice to Hélène:

Vivez, si m'en croyez, n'attendez à demain:

Cueillez dés aujourd'huy les roses de la vie.

'Live now, if you heed me; don't wait for tomorrow; gather today the roses of your life'.

With this summation, the speaker offers his carpe diem advice, derived as we have seen from Catullus in its first hemistich and from Ausonius in the remainder. The poem ends with this demonstration of virtuoso talent and hard work, issuing from its author's professional competence in adapting the verses of classical poets to his own situation. 
The conclusion accordingly registers a decisive victory of the speaker's morale over the beloved's intransigence, but it is not especially Hélène's character that this victory targets with aggression. It is a system of court poetry that falls under attack - the posturing and pleading and vying for patronage by exploiting conventional themes favored by a sometimes philistine readership. Hélène's ingratitude functions as a mirror of this system, replicating the ingratitude of a broader readership that includes even the poet's royal sponsors. To the queen-mother who has requested these poems for Hélène, the author had earlier dedicated his Discours des Miseres de ce temps as an act of public service to heal a nation corrupted by civil war. For this voluntary gift, he has reaped no tangible reward. Yet other gifts of poetry, likewise proffered in a spirit of self-sacrifice, receive no acknowledgment. The speaker's complaint in Quand vous serez bien vielle re-directs his economic self-interests toward expectations of an affective return from Hélène for his benefaction to her. When she does not reciprocate, he compensates by celebrating his poetic autonomy and anticipating his poetic fame.

Ronsard's choice of Tibullus and Ausonius as models for the opening and closing lines of this sonnet reflect his concern with recognition and reward. As it happens, the poet's chief competitor at court - Philippe Desportes - had also used Tibullus as a model for his poetry. In addition to serving Ronsard for Quand vous serez bien vieille, Tibullus's elegy 1.3.84-88 served Desportes for an epigram published in his Oeuvres of I575, Je t'apporte, ô Sommeil 'I bring to you, o Sleep'. ${ }^{20}$ Its speaker promises a votive offering to the god of slumber if he causes the beloved Y sabeau's chambermaid to fall asleep:

Tant qu'Alison, la vieille accroupie au foyer Laisse choir le fuseau, cesse de babiller, Et de toute la nuict ne se puisse eveiller.

'So that Alison, the old woman hunched by the fireplace, might let her spindle fall and cease babbling, and for the entire night not be able to wake up'.

Assigned to the chambermaid, the phrase «la vieille accroupie an foyer» (elaborating upon Tibullus's «adfixa puella» 'the maid bent over her task' and 'positaque lucerna» 'when the lamp is in its place') anticipates Ronsard's fantasy of Hélène as an old woman «au fouyer une 
vieille accroupie». Whereas the goal of Desportes's speaker is to enjoy intimacy with Ysabeau - "Afin qu'à mon plaisir j'embrasse ma rebelle» 'In order that I might embrace my little rebel for my pleasure'the goal of Ronsard's speaker is to declare his poetic talents and secure them for his poetic fame. It is also to cast Hélène into a compromising position by pressuring her to admit that her beauty is fleeting and that it is wise to enjoy pleasure while she can.

Ronsard accomplishes this last goal by evoking Catullus and especially Ausonius in their exhortations vivamus and collige rosas (rendering the former as "Vivez" and the latter as "Cueillez les roses de la vie»). As it happens, Ronsard himself had already used these texts for models in his own earlier poetry. Ausonius served bim especially in his ode I.I7, Mignonne, allons voir si la rose 'Mignon, let us go see if the rose' (originally published in an appendix to the second edition of Les Amours in I553). Both Catullus and Ausonius served him on other occasions in carpe diem poems addressed to Marie de Bourgueil in his Le second livre des Amours. ${ }^{2 \mathrm{I}}$ Now in his poems for Hélène, Ronsard displays his professional competence by seamlessly evoking classical and Petrarchan texts as though in dialogue with one another. Through Petrarch's model of imagining the beloved in old age, he channels Horace's and Tibullus's poems about future projections as well as Catullus's and Ausonius's poems of carpe diem advice. The effect is a polyphonic intertextuality, for which there is no counterpart in Desportes's largely monophonic borrowing from Tibullus. In this case, Ronsard's journey from Tibullus to Ausonius across the expanse of his Petrarchan model figures the movement of his own career from his earliest sonnets to Cassandre in Les Amours onwards, beyond frontiers approached or even imagined by Desportes. In effect, Quand vous serez bien vieille, au soir à la chandelle fuses each of its Petrarchan models, and suspends them in a distillation of reminiscences from the carpe diem motif in classical Latin poetry.

Hélène's intransigence provides a staging ground for these ancient as well as modern texts to dramatize the dynamics of an unequal exchange between lovers. The poet embarks upon his literary journey not just with Petrarch and but also with such Roman poets as Horace and Tibullus, Catullus and Ausonius, those ancients who themselves had attracted Petrarch's attention. Their conjunction maps out an historical canon of ancient and modern European lyric poetry, now shar- 
ply reduced to the narrow confines of courtly patronage that pits Ronsard against an otherwise companionable colleague, the young Philippe Desportes. Ronsard's quest for discovery and recognition prompts his engagement with a variety of genres, not just the Petrarchan sonnet, the Horatian ode, the Tibullan elegy, the Catullan song, and the Ausonian idyll, but also such longer, more philosophical and complex forms as verse Discours, the strophaic ode, the dodecasyllabic elegy, and the decasyllabic epic. But the courtly context pressures him to strategize with entrepreneurial skills in order to shape these resources into something new. Far from responding to this turn of events with cynicism or despair, Ronsard welcomes it. If anything, he embraces Petrarchism from the perspective of craftsmanship as an exceptionally challenging mode to reinvent. Quand vour serez bien vieille, au soir à la chandelle traces this literary bistory in its own poetic form.

William J. Kennedy 
I. Quotations from, and numbering of, Ronsard's poems refer to PIERrE DE Ronsard, Oeuvres complètes, ed. Jean Céard, Daniel Ménager, and Michel Simonin, Bibliothèque de la Pléiade, 2 vols. (Paris: Gallimard, I993-94).

2. Binet, La vie de Ronsard, ed. Paul Laumonier (Paris: Hachette, I 90I), p. 26. Binet writes that Ronsard's love for Hélène was entirely chaste and unconsumated («Tesmoin le titre qu'il a donné à ses loüanges [,] imitant en cela Petrarque») which Laumonier understands as the poet's decision to forego the title Les Amours de Hélène on the model of his two earlier Les Amours, in favor of Sonnets pour Hélène I et II on the model of the title most commonly assigned to Petrarch's Italian poems in the sixteenth century, Sonnetti e canzoni in vita e in morte di Madonna Laura (Laumonier, ed., Vie, p. 166).

3. In service to the queen-mother as a maid-of-honor since at least May i 566 , Hélène was the daughter of a minor nobleman from Clermont-Surgères, a distant cousin of the Comtesse de Retz, and evidently a regular at the latter's literary salon; unmarried, she had been engaged in her teens to Jacques de la Rivière who died in 1569 fighting in the civil war; see Yvonne Bellanger, «Un personage poétique nouveau: Hélène dans les Amours de Ronsard», Quaderni dell'Istituto di lingue e letterature neo-latine, 2 (1982), pp. 7-26; Michel Simonin, Pierre de Ronsard (Paris: Fayard, 1990), pp. 335-39; and Simonin, «Hélène avant Surgères», in Marcel Tetel, ed., Sur des vers de Ronsard (Paris: Aux Amateurs de Livres, 1989), pp. I $27-40$.

4. Ronsard, Céard ed., I.996.

5. Ronsard, Céard ed., I.626. Ronsard wrote the ode in June I 550 and published it in the first edition of Les Amours three years later; in I 55 he added it to his first book of odes where it remains as poem r.Io in all subsequent editions. See Josiane Rieu, «Fureur et passion dans Les Amours de Ronsard», in A Poétique des passions à la Renaissance (Paris: Champion, 200I), pp. 73-89.

6. See Jean Balsamo, «Le 'Pétrarquisme' des Amours de Ronsard», Revue d'Histoire Littéraire de la France, 98 (1998), pp. 179-93; for Ronsard's treatment of metaphor and mythology in Les Amours, see François Rigolot, Le texte de la Renaissance (Geneva: Droz, 1982), pp. 187-219 and 253-65.

7. See, for example, sonnet 7I, Ja desja Mars mon triomphe avoit choise.

8. See sonnet i I, Ab traistre Amour, donne moy paix ou trèfve, with its echo of Marot's rondeau 29; sonnet 43, Ores la crainte et ores l'esperance, with its echoes of Scève's dizains 65 and 68; sonnet 57, Divin Bellay, dont le nombreuses lois, with its response to sonnet 60 of Du Bellay's Olive; and sonnet I 4I, L'astre ascendant, soubz qui je pris naissance, with its echo of Tyard's Erreurs amoureuses I.4I.

9. See sonnet 6, Douce, belle, amoureuse, bien-fleurante Rose, inspired by Propertius and Tibullus, originally in the Continuation des Amours (I 55); sonnet 23 Morfée, si en songe il te plaist presenter, inspired by Marullus, originally in Le Bocage (I 5 54); sonnet 32, J'ay pour maistresse une etrange Gorgonne, originally in Les Melanges (1 555); and sonnet 44, Marie baisez moy, non: ne me baisezpas, inspired by Johannes Secundus, originally composed as a sonnet for Sinope, Sinope baisez moy, in Second livre des Meslanges ( I 559). 
ı. See Jacques Lavaud, Un poète de cour au temps des derniers Valois, Philippe Desportes (Paris: Droz, I936), pp. I-9. Lavaud speculates that Desportes likely spent some early years in Rome and pursued his advancement at the Valois court in Paris. Upon Henri IV's ascent to the throne, he retreated to a comfortable life at his various benefices where he translated Psalms and composed religious verse. See Michel Simonin, «Desportes au palais et aux champs, (I $583-1606$ )», in Jean Balsamo, ed., Philippe Desportes (I546-1606): Un poète presque parfait entre Renaissance et classicisme (Paris: Kincksieck, 2000), pp. 37-86.

I I. For Ronsard's treatment of the mythic Helen, see Nathalie Dauvois, Mnémosyne: Ronsard, une poétique de la mémoire (Paris: Champion, I 992), pp. 203-205; for Ronsard's self-representation as an old man, see Sara Sturm-Maddox, Ronsard, Petrarch, and the "Amours" (Gainesville: UP of Florida, I999), pp. I08-27.

I 2. See inter alia Ronsard, Les Amours, ed. Henri and Catherine Weber (Paris: Garnier, I963., p. 757; Sonnets pour Hélène, ed. Malcolm Smith (Geneva: Droz, i 970), pp. I48-49; and Céard ed., I.I 391.

I 3. Quotations from Catullus and Tibullus, Poems and 'Pervigilium Veneris', ed. and trans. J.P. Postgate et al. (London: Heinemann, i9 3 3).

I4. Quotations from Ausonius, Works, ed. and trans. Hugh G. Evelyn White, 2 vols. (London: Heinemann, I9I9-2 I).

I 5. Quotations from Francesco Petrarca, Canzoniere, ed. Marco Santagata, 3 ed. (Milan: Mondadori, 2008); translation by Robert Durling, Petrarch's Love Poems (Cambridge, Mass.: Harvard UP, 1976).

i6. Quoted from Horace, The Odes and Epodes, ed. and trans. C.E. Bennett (London: Heinemann, I9I4).

17. See Phebe Lowell Bowditch, Horace and the Gift Economy of Patronage (Berkeley: U California P, 200I), pp. 31-63.

i 8. Quotations from Pietro Bembo, Prose e rime, ed. Carlo Dionisotti (Turin: UTET, I 960). Sonnet I 2 had already prompted imitations by Petrarch's first disciple, Giovanni Boccaccio, in two sonnets, L'alta speranza and S'egli avvien mai (though it is unlikely Ronsard knew either of them, since they remained unpublished until the twentieth century),

19. For Ronsard's use of Giolito's anthologies and Bembo's models, see JoAnn DellaNeva, Unlikely Exemplars (Newark: U Delaware P, 2009), pp. 222-89, especially pp. $255-63$.

20. Quoted from Desportes, Diverses amours, ed. Victor E. Graham (Geneva: Droz, 1963), p. 205.

2 I. See especially Je vous envoye un bouquet que ma main, originally in the Continuation des Amours of i 55 , then incorporated as sonnet 6 in Le second livre des Amours for Marie in I 560 , and finally dropped from that sequence in 1578 upon the publication of the poem derived from it, Quand vous serez bien vieille, in Sonnets pour Hélène. 